\title{
NADPH-diaphorase activity in area 17 of the squirrel monkey visual cortex: neuropil pattern, cell morphology and laminar distribution
}

\author{
J.G. Franca ${ }^{1,2}$, \\ J.L.M. do-Nascimento ${ }^{1}$, \\ C.W. Picanço-Diniz' \\ J.A.S. Quaresma ${ }^{1}$ \\ and A.L.C. Silva ${ }^{1}$
}

\author{
12Departamento de Fisiologia, Centro de Ciências Biológicas, \\ Universidade Federal do Pará, Belém, PA, Brasil \\ ${ }^{2}$ Programa de Neurobiologia, Instituto de Biofísica Carlos Chagas Filho, \\ Universidade Federal do Rio de Janeiro, Rio de Janeiro, RJ, Brasil
}

\author{
Correspondence \\ J.G. Franca \\ Laboratório de Neurobiologia 2 \\ Instituto de Biofísica, UFRJ \\ CCS, Bloco $\mathrm{G}, 2^{\circ}$ andar \\ 21949-900 Rio de Janeiro, RJ \\ Brasil \\ Fax: 55 (021) 280-8193 \\ E-mail: jgfranca@ibccf.biof.ufrj.br \\ Research supported by \\ FINEP/FADESP \\ UFPA/PROPESP and CNPq.

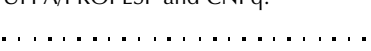

Received October 25, 1995

Accepted July 10, 1997

\begin{abstract}
We studied the distribution of NADPH-diaphorase activity in the visual cortex of normal adult New World monkeys (Saimiri sciureus) using the malic enzyme "indirect" method. NADPH-diaphorase neuropil activity had a heterogeneous distribution. In coronal sections, it had a clear laminar pattern that was coincident with Nissl-stained layers. In tangential sections, we observed blobs in supragranular layers of V1 and stripes throughout the entire V2. We quantified and compared the tangential distribution of NADPH-diaphorase and cytochrome oxidase blobs in adjacent sections of the supragranular layers of V1. Although their spatial distributions were rather similar, the two enzymes did not always overlap. The histochemical reaction also revealed two different types of stained cells: a slightly stained subpopulation and a subgroup of deeply stained neurons resembling a Golgi impregnation. These neurons were sparsely spined non-pyramidal cells. Their dendritic arbors were very well stained but their axons were not always evident. In the gray matter, heavily stained neurons showed different dendritic arbor morphologies. However, most of the strongly reactive cells lay in the subjacent white matter, where they presented a more homogenous morphology. Our results demonstrate that the pattern of NADPH-diaphorase activity is similar to that previously described in Old World monkeys.
\end{abstract}

\section{Introduction}

NADPH-diaphorase (NADPHd) activity in the central nervous system has been studied since Thomas and Pearse (1) described the "solitary cells" that survive various neurodegenerative and ischemic insults $(2,3)$. NADPHd histochemistry has revealed the distribution of nitric oxide synthase in fixed tissue (4). Brain nitric oxide synthase (bNOS) is a calcium/calmodulin-dependent enzyme
Key words

- Nitric oxide synthase

- Neocortex

- NADPH-diaphorase

- Cytochrome oxidase

- Primates
(5) that synthesizes nitric oxide (NO) through NMDA receptor activation (6). NO is a gas that might act as a diffusible retrograde messenger that enhances the activation of the presynaptic terminal (6).

The identification of NADPHd as the enzyme responsible for NO synthesis was accomplished by biochemical and immunohistochemical procedures (7-9). This finding led to the utilization of histochemical methods for localizing NOS in neural tissue 
(10). Thus, a simple histochemical procedure allows detailed localization of NOS in fixed material. NOS utilizes NADPH as a cofactor to reduce the chromogen nitroblue tetrazolium, a yellowish salt, to diformazan that has a bluish appearance. This approach has been widely used to study the central nervous system of many non-primate species including rats $(10,11)$, guinea pigs (12), opossums (13) and cats (14). In a previous report, Sandell (15) described the pattern of NADPHd activity in the visual cortex of the Rhesus monkey. Until recently there were no data on the distribution of this enzyme in the visual cortex of New World monkeys.

In the present study we used the "indirect" histochemical method to describe the morphology and laminar distribution of reactive neurons of the squirrel monkey. This animal presents some remarkable differences in the organization of neocortical architecture (16). We wondered if any difference in the NADPHd pattern could be detected, regarding neuropil distribution and cell distribution and morphology. We also quantified the distribution of NADPHd and cytochrome oxidase activities in the neuropil of supragranular layers in order to detect any difference in the blob pattern revealed by these two different enzymes. No quantitative data on the distribution of NADPHd in New World monkeys have been published.

\section{Material and Methods}

Five adult Saimiri sciureus monkeys (three males and two females) were deeply anesthetized with an overdose of barbiturate (200-400 mg/kg Thionembutal). The animals were subsequently perfused through the left ventricle with $0.9 \%$ saline followed by $4 \%$ paraformaldehyde in $0.1 \mathrm{M}$ sodium phosphate buffer (PB), pH 7.2-7.4, followed by cryoprotective sucrose solutions. About 1 liter of each solution was used for perfusion. Cryoprotectant solutions were essential to keep the tissue well preserved during and after freezing microtomy. Thick microtome sections (100-200 $\mu \mathrm{m})$ were washed 3 times in $0.1 \mathrm{M}$ PB for $10 \mathrm{~min}$ each and then incubated with the histochemical solutions. For NADPHd histochemistry, free-floating sections were incubated in a solution containing $0.6 \%$ malic acid, $0.03 \%$ nitroblue tetrazolium (NBT), $1 \%$ dimethylsulfoxide, $0.03 \%$ manganese chloride, $0.1 \%$ ß-nicotinamide adenine dinucleotide phosphate (Sigma Chemical Co., St. Louis, MO) and 3\% Triton $\mathrm{X}-100$ in $0.1 \mathrm{M}$ Tris, $\mathrm{pH}$ 8.2. The cytochrome oxidase solution consisted of $0.06 \%$ diaminobenzidine (Sigma), $0.03 \%$ cytochrome c (Sigma) and 4.5\% saccharose in $0.1 \mathrm{M} \mathrm{PB}$. The sections were incubated under continuous shaking at $37^{\circ} \mathrm{C}$ for about $6 \mathrm{~h}$.

After the histochemical procedures, the sections were rinsed in $0.1 \mathrm{M}$ Tris buffer, $\mathrm{pH}$ 7.4 , mounted on gelatinized slides, dehydrated and coverslipped using DPX or Entellan as embedding medium. Five hemispheres, one from each animal, were used to obtain complete series of the occipital lobe in four section planes (parasagittal, coronal, horizontal and tangential). Sections from these hemispheres were treated to detect NADPHd activity and some sections were selected for Nissl counterstaining.

Bidimensional reconstructions of cells in these hemispheres were obtained by means of a camera lucida attached to a light microscope equipped with a bright field condenser. NADPHd-reactive neurons displaying detailed dendritic and/or axonal morphologies were drawn. Three additional hemispheres were cut tangentially to compare the spatial distribution of cytochrome oxidase and NADPHd-rich zones (blobs) in different layers. In these hemispheres, alternate sections were treated to detect each enzyme. The contours of NADPHd and cytochrome oxidase blobs were drawn and their areas measured. Blob centroids were estimated in order to evaluate their spatial distribution by means of nearest neighbor analysis. 


\section{Results}

NADPH-diaphorase neuropil activity compared to cytochrome oxidase pattern

The bluish appearance of formazan was dispersed as a background activity that revealed NADPHd-reactive neuropil. Strong reactive regions were dark blue. Intense and light stained neuropil regions were organized in a fashion related to cortical layers. A clear laminar pattern was observed from pial surface to white matter. This was equivalent to cortical layers $1,2 / 3,4 \mathrm{~A}, 4 \mathrm{~B}, 4 \mathrm{C}, 5$ and 6 (Figure 1A,C,D). Layer 1 presented a number of NADPHd-positive fibers running parallel to the pial surface. Just below this layer and bordering layer 2 we found a thin layer virtually devoid of NADPHd activity. The limit between layers 2 and 3 was not well defined. NADPHd-rich zones in the neuropil formed rows of blobs (Figure 1A) which could be better observed in tangential sections through layers 2 and 3 (see below). NADPHd blobs could not be found in infragranular layers. Layer $4 \mathrm{~A}$ was thin and more densely stained than the adjacent layers 3 and 4B (Figure 1A,C,D). All layers presented faint longitudinal striations (17) better recognized in well-stained layers using high power microscopy (layer $4 \mathrm{C}$ is the best example). In tangential sections, layer $4 \mathrm{~A}$ did not present the honeycomb pattern described in Rhesus monkeys $(15,17)$. Layer $4 \mathrm{C}$ was clearly labeled. This is a distinctive architectural feature of V1 that can be used to limit this cortical area. The border of this layer with the underlying layer 5 showed an even more intense NADPHd activity. This darker region comprised about $1 / 5$ of layer $4 \mathrm{C}$ as a whole. Layers 5 and 6 were much less intensely stained than the other laminae. Layer 6 showed slightly higher NADPHd activity than layer 5 (Figure 1A,C).

In tangential sections, the distinction between V1 and V2 was very clear because of the blob and stripe patterns, respectively
(Figure 2A). In V1, NADPHd- (Figure 2B) and cytochrome oxidase-rich zones (Figure 2C) appeared as rows of blobs separated by interblob regions where enzymatic activity was poor. Most of the blobs were isolated and rounded. In some instances, blobs were linked by bridges of higher neuropil activity. The $t$-test applied to samples from adjacent sections treated to detect NADPHd or cytochrome oxidase activity (Figure 3A,B) pointed to significant differences between blob areas revealed by cytochrome oxidase $\left(36,280 \mu \mathrm{m}^{2}, \mathrm{~N}=126, \mathrm{SD}=11,884\right)$ and NADPHd $\left(42,582 \mu \mathrm{m}^{2}, \mathrm{~N}=121, \mathrm{SD}=\right.$ 14,272, 2-tailed $t$-test, $\mathrm{P}<0.001$ ) (Figure $3 \mathrm{~A}, \mathrm{~B})$. Nearest neighbor blob distances were similar when NADPHd and cytochrome oxidase were compared ( $375 \times 364 \mu \mathrm{m}$, respectively, 2-tailed $t$-test, $\mathrm{P}=0.546, \mathrm{~N} 1=126$, $\mathrm{N} 2=130, \mathrm{SD} 1=65.8, \mathrm{SD} 2=65.3$ ) (Figure 3C,D). The spatial distribution of the two blob systems was not random. Nearest neighbor distances of NADPHd or cytochrome oxidase blobs were significantly different from nearest neighbor distances measured in a random dot pattern of the same area and density $(\mathrm{P}<0.05)$ (Figure 3E). Additionally, in the operculum the number of NADPHd blobs per $\mathrm{mm}^{2}$ of striate cortex was, on average, quite similar to that reported by Horton (17) in Rhesus monkey $\left(4.6 / \mathrm{mm}^{2} \mathrm{x}\right.$ $4.8 / \mathrm{mm}^{2}$, respectively).

The spatial relationship between the two enzymes was further investigated by aligning adjacent cytochrome oxidase and NADPHd sections using blood vessels as landmarks. Figure 4 shows the result of this procedure for the equivalent fields depicted in Figure 2B and C. Although the two enzymatic systems have a similar spatial distribution they are not identical.

Neuropil activity in area V2 appeared as thin $(0.4 \mathrm{~mm})$ and thick $(0.7 \mathrm{~mm})$ stripes separated by interstripe regions. NADPHdand cytochrome oxidase-rich zones were roughly congruent in V2 when compared to adjacent sections. NADPHd center-to-cen- 

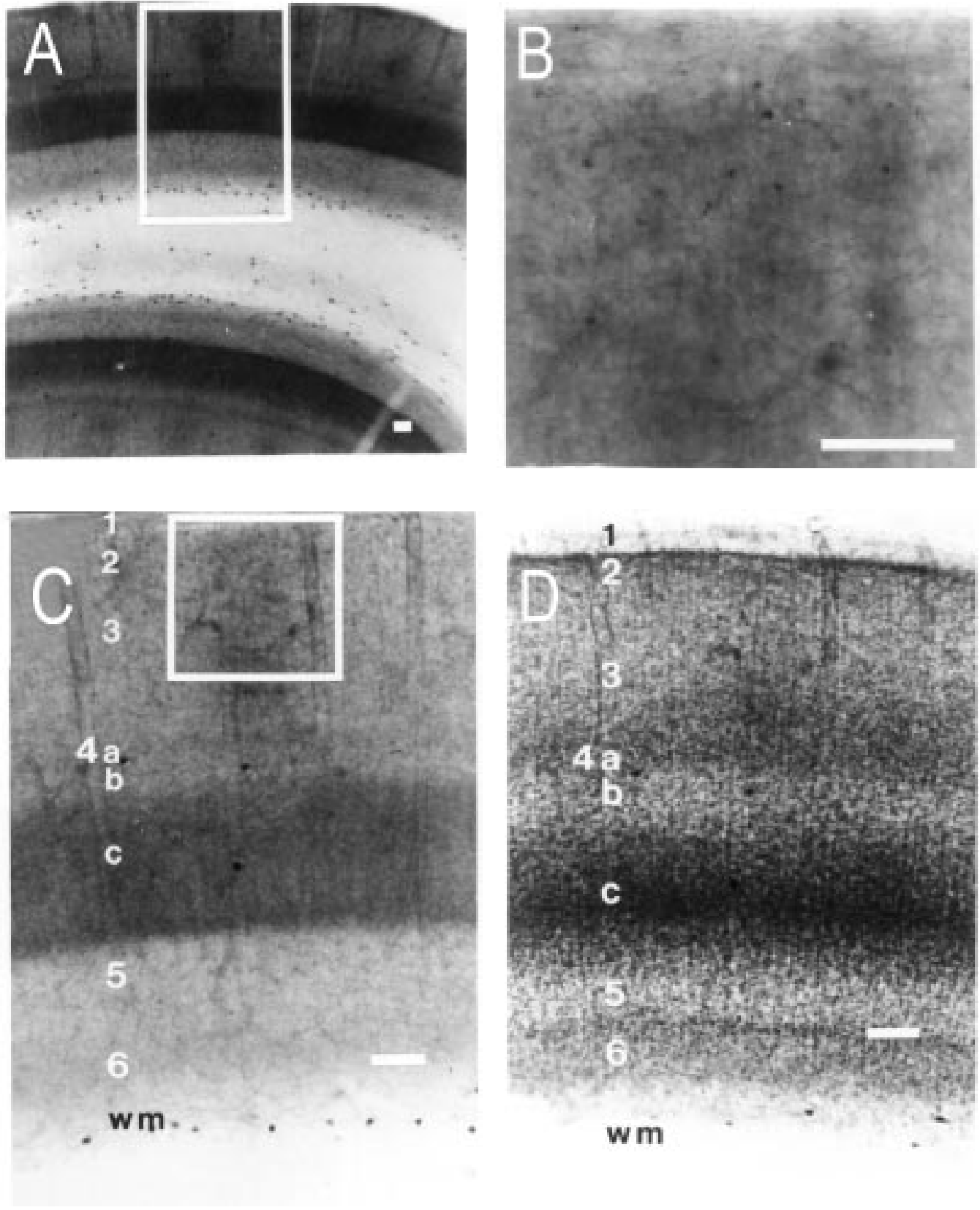

Figure 1 - Parasagittal section through area 17 of a squirrel monkey processed for NADPH-diaphorase activity and then stained with cresyl violet. A, Low magnification before cresyl violet stain. NADPH-diaphorase-positive neuropil provides a clear laminar pattern and blobs in supragranular layers. Some NADPH-diaphorase-positive neurons can be seen as dark dots in the white matter ( $w m$ ). The region enclosed in the box is magnified first in $C$ and then in B. B, Higher magnification of the supragranular neuropil activity enclosed in the box shown in $\mathrm{C}$. The cell bodies of some weakly stained NADPH-diaphorase-positive cells can be seen. $C, N A D P H$-diaphorase cortical lamination is coherent with the pattern obtained after cresyl violet staining (shown in D). D, Same section as in $C$ after cresyl violet staining. Scale bar $=100 \mu \mathrm{m}$. 
ter thin stripe and thick stripe distances were $2 \mathrm{~mm}(\mathrm{SD}=0.5 \mathrm{~mm})$ and $1.5 \mathrm{~mm}(\mathrm{SD}=0.4$ $\mathrm{mm})$, respectively. Thin stripes extended from the anterior border of V1 to the anterior margin of V2. Different from thin stripes, thick stripes did not touch the V1/V2 border. Both types of stripes seemed to present irregular enzymatic activity, suggesting the occurrence of separate compartments along the stripe. These compartments were characterized by zones rich in enzymatic activity isolated by thin paler transverse regions (Figure $2 \mathrm{~A})$. The anterior limit of V2 could be identified by the disappearance of the stripe pattern.

\section{Morphology and distribution of NADPH-diaphorase-positive neurons}

In addition to neuropil activity, NADPHdiaphorase revealed two different subpopulations of labeled cells that were not observed by means of cytochrome oxidase histochemistry. The first group of cells was composed of a large number of small lightly stained NADPHd-positive somata. Labeling of these cells was so faint that only their cell bodies could be observed by light microscopy (Figure 1B). Primary processes could be distinguished in a few cases. These cells were found to be scattered throughout all layers but they were much more numerous in laminae 2 and 3. Modifications in fixation procedures could intensify their labeling. Lightly labeled cells were much more nu-
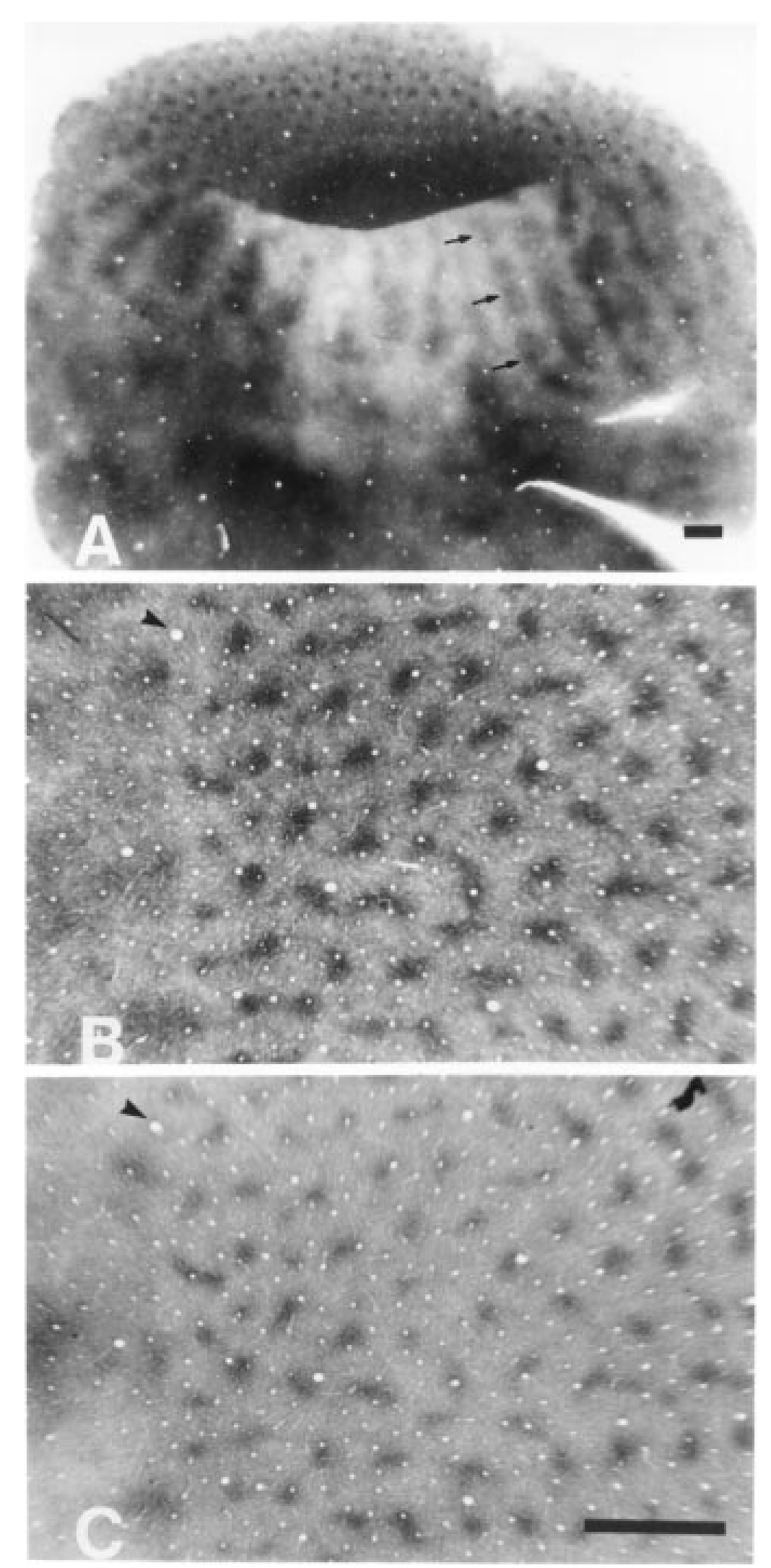

Figure 2 - Tangential sections through opercular supragranular layers of $\mathrm{V} 1$. A, Low magnification photomicrograph of a tangential section reacted for NADPH diaphorase. The blobs can be seen as small dots in $\mathrm{V} 1$. Different from the anterior limit of $\mathrm{V} 2$ with other extrastriate areas, the V1/N2 border is sharply defined. V2 stripes are also evident and present irregular enzymatic activity (arrows) along their extent. $B$, Section stained for NADPH diaphorase. $C$, Section processed for cytochrome oxidase. The arrowheads in $\mathrm{B}$ and $\mathrm{C}$ point to corresponding blood vessels. Scale bar $=1.0 \mathrm{~mm}$. 
Figure 3 - Quantitative analysis of blob distribution in a tangential section. $A$ and $B$, Histograms of blob areas as measured in the section reacted for diaphorase (A) and cytochrome oxidase (Cytox) (B). C, D and E, Histograms of nearest neighbor distances between blobs in the section processed for diaphorase $(C)$, and cytochrome oxidase (D). These distributions are different from that obtained for a random dot pattern of the same density (E).
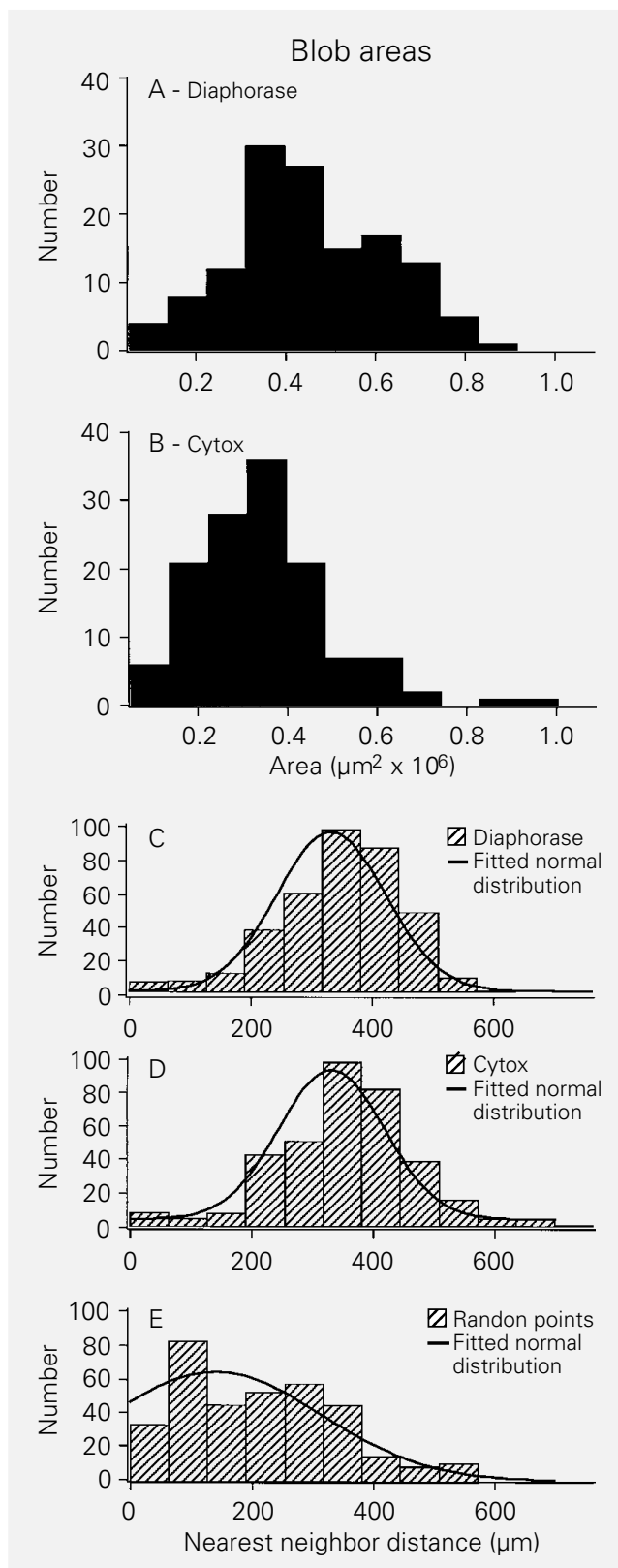

merous in tissue processed by light paraformaldehyde fixation (i.e., tissue exposed to fixative for less than $20 \mathrm{~min}$ and/or using lower concentrations of paraformaldehyde) or using glutaraldehyde as fixative (data not shown).

The second subpopulation of labeled cells presented fine anatomical details both in dendrites and axons (Figure 5). Similar to what is observed with Golgi staining, the neuron processes and soma were so strongly labeled that we were not able to identify organelles or the cell nucleus. However, NADPHd-positive cells were much more frequent than Golgi-impregnated neurons in all cortical layers. In area 17 gray matter, the distribution and morphology of these NADPHd-positive neurons were heterogeneous. The axons of NADPHd-positive cells were usually very thin and faintly stained. They could be followed for more than 200 $\mu \mathrm{m}$ from the cell body in one typical neuron (Figure 5D). In some cases, they could be followed for more than $1 \mathrm{~mm}$ (e.g., layer 5 or white matter cells projecting up to layer 1 , data not shown). Axons could arise from any point in somata or primary dendrites and followed an ascending or descending initial course that could be changed in a recurrent trajectory giving rise to a number of short collaterals (e.g., Figure 5B). In most cases we observed boutons "en passant" (18) and, in a few cases, "club like" boutons (18) that were suggestive of synaptic sites.

All stained neurons were non-pyramidal sparsely spined cells which resembled the neurons described by Peters and Regidor (19) except for the fact that NADPHd neurons presented many varicosities along the dendrites. Gray matter neurons had cell bodies of different shapes. Dendritic arborization also varied from one neuron to another. NADPHd-positive cells showed dendritic arborization in the immediate vicinity of the cell body. Some of the NADPHd-positive neurons had dendritic trees that were elongated in opposite directions (Figure 5B). These neurons were similar to the bi-tufted cells reported by Fairén et al. (20). We did not detect any strict correlation between the pattern of dendritic arborization and laminar position. However, there were some exceptions. At the bottom of layer 6, most neurons had horizontally oriented dendrites which resembled the neurons impregnated by the Golgi staining method described by Tömböl (21). Another exception was layer $4 \mathrm{C}$ neu- 
rons. In some cases, these neurons had dendritic arborizations facing up towards supragranular layers (Figure 5C). Neurons with dendritic arborizations oriented in the opposite direction were rare but could also be found. Generally, when the cell body was near the border of the layer, dendrites tended to stay inside the resident layer, recurving up or down to avoid adjacent layers. This particular case was frequent in layer $4 \mathrm{~B}$, but could also be observed in other layers such as $4 \mathrm{C}$ and 5. This was not a stringent rule since some neurons spread out their dendrites irrespective of laminar borders.

One of the most remarkable aspects of NADPHd histochemistry is that it permits the visualization of a very dense subpopulation of neurons in the white matter
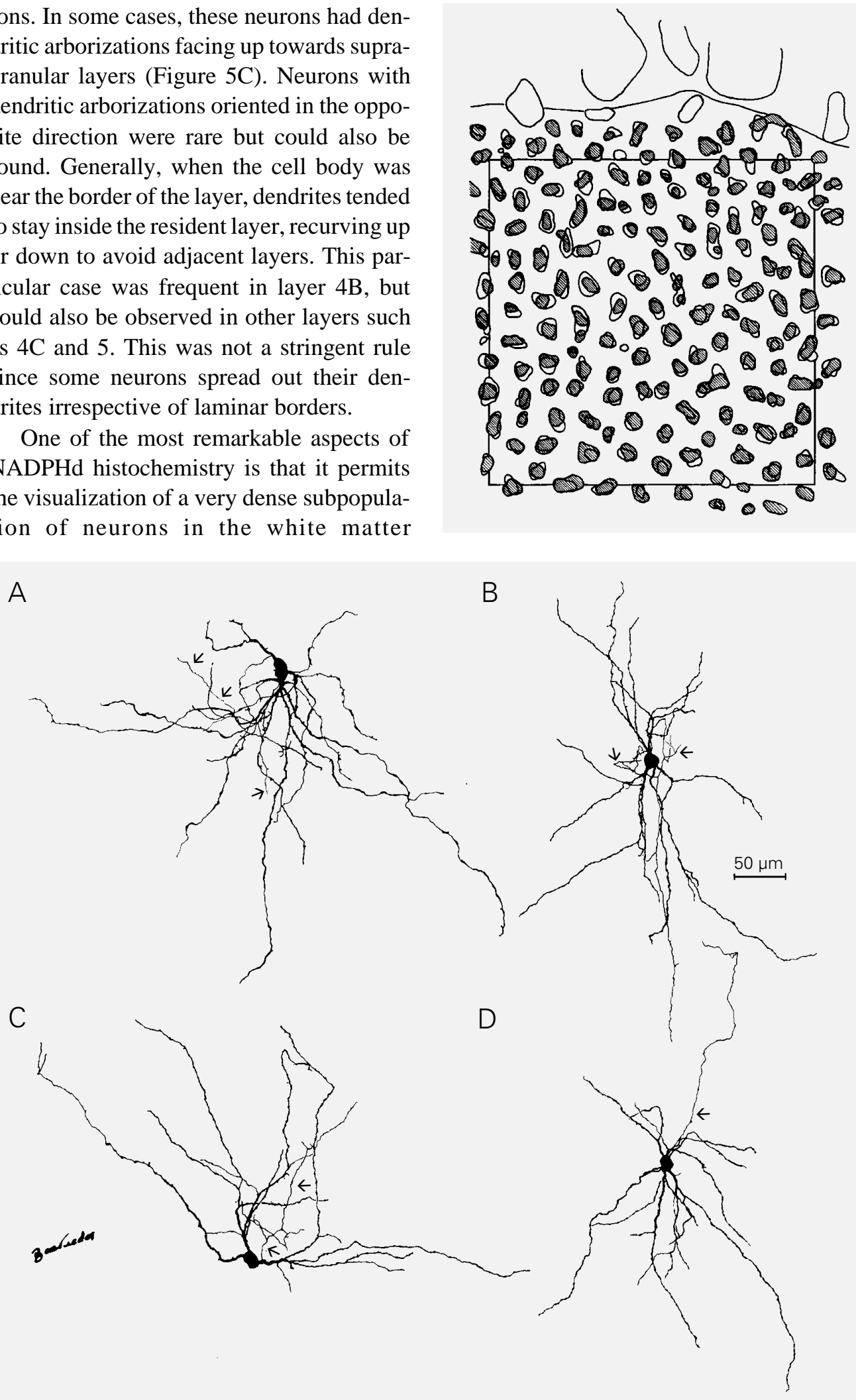

Figure 4 - Camera lucida drawing representing the superimposed blob pattern obtained by using the blood vessels as landmarks. The same sections as illustrated in Figure $2 \mathrm{~B}$ and $2 \mathrm{C}$ were used. Blobs revealed by cytochrome oxidase histochemistry are hatched. Area of the square is $25 \mathrm{~mm}^{2}$.
Figure 5 - Camera lucida drawings of NADPH-diaphorase-positive neurons from different cortical layers of $\mathrm{V} 1$ gray matter as seen in a parasagittal section. Although their dendritic arborization seems quite variable, none of the cells are pyramidal. Supragranular layer neurons $(A, B)$, layer $4 \mathrm{C}$ neurons $(\mathrm{C})$, and a neuron from layer 5 (D) are illustrated. The arrows point to axons. 
Figure 6 - Photomicrograph of cortical tissue cut tangentially at the white matter level. Numerous NADPH-diaphorase neurons seem to be distributed randomly, forming a net of considerable dendritic overlap. Scale bar $=500 \mu \mathrm{m}$
(Figure 6). These neurons have not been identified previously by means of any other technique in the adult brain (15). In V1, most NADPHd neurons were in the white matter (considering just the first $150 \mu \mathrm{m}$ below the inferior border of layer 6). These neurons comprised about $80 \%$ of the total population of heavily labeled cells (laminar distribution in V1 gray matter was the following: supragranular layers $=11.9 \%$, layer $4 \mathrm{C}=3.3 \%$, infragranular layers $=4.1 \% ; \mathrm{N}=2256$ ). White matter cell distribution and morphology were more homogeneous than those of gray matter neurons. In non-tangential sections, white matter cells exhibited dendritic arborization oriented along the tangential plane. Some dendrites extended to the gray matter. In tangential sections, white matter cell dendrites displayed a radial distribution (Figures 6 and 7), a pattern suggesting that these neurons might form a neural network with significant dendritic overlap. Axons of these neurons extended towards the white and/or gray matter. Additionally, some of these

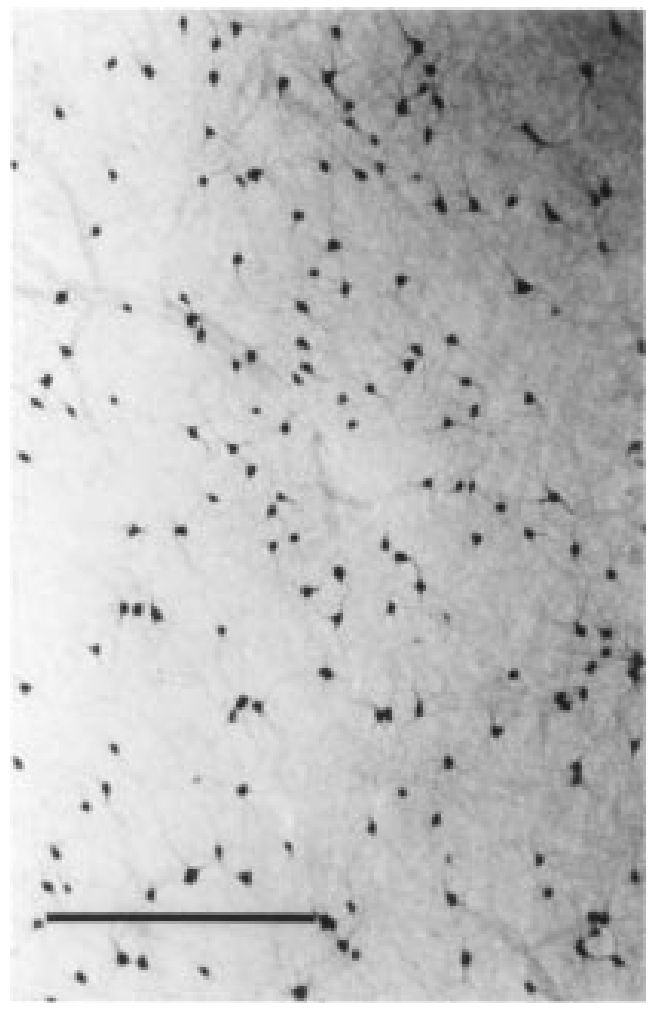

axons bifurcated after a few hundred micrometers giving off many short collaterals. In a few cases, we followed axons from white matter cells up to layer 1 . These axons had many thin collaterals and often presented boutons "en passant". Terminal boutons were less frequent.

In the white matter we also identified many thick NADPHd-positive axons that could not be attributed to any of the reactive cells in the section. These axons could be observed in a course parallel to the pial surface and were 2 to 3 times thicker than axons of neocortical NADPHd neurons. These thick axons could be followed for more than $1 \mathrm{~mm}$ before being sectioned on the surface of the slice. We do not know the origin or the target of these axons, but we think they may arise from subcortical projections since their morphology was different from that of axons of cortical NADPHdpositive cells.

Since no remarkable qualitative morphological differences could be assigned to the neurons from different cortical areas or from gray $v s$ white matter, we decided to compare soma areas of well-impregnated NADPHd neurons in V1, V2 and white matter. V1 soma areas ranged from 98 to $240 \mu \mathrm{m}^{2}$ (mean $\left.=154 \mu \mathrm{m}^{2}, \mathrm{~N}=182, \mathrm{SD}=32.9 \mu \mathrm{m}^{2}\right)$. No remarkable difference could be found in V2, that had similar soma areas $($ mean $=144.5$ $\left.\mu \mathrm{m}^{2}, \mathrm{~N}=100, \mathrm{SD}=29.2 \mu \mathrm{m}^{2}\right)$. Neurons from different stripes in $\mathrm{V} 2$ had similar soma areas. White matter soma areas were significantly larger $\left(\right.$ mean $=222.8 \mu \mathrm{m}^{2}, \mathrm{~N}=104$, $\left.\mathrm{SD}=52.2 \mu \mathrm{m}^{2}, \mathrm{P}<0.001\right)$ than $\mathrm{V} 1$ gray matter neurons.

In parasagittal, coronal and horizontal sections dendritic field areas of V1 gray matter neurons were also measured. No correlation between soma area and dendritic field area could be detected.

In tangential sections, the number of cells counted in supragranular layers of V1 was three times higher in interblobs than inside blobs. However, inasmuch as the interblob 
area is proportionately larger than the sum of all blob areas, there was no difference in terms of cell density inside and outside blobs. Thus, NADPHd neurons seemed to be randomly distributed in area 17 supragranular layers, showing no preference for blobs or interblob regions.

\section{Discussion}

NADPH-diaphorase activity in brain tissue reveals soluble nitric oxide synthase activity in paraformaldehyde-fixed material (4). Although particulate NOS can be demonstrated histochemically using glutaraldehyde as a fixative, this isoform seems to predominate in brain regions other than the neocortex (22). Aoki et al. (23) provided further evidence that in V1 NADPHd and nitric oxide synthase are co-localized in macaques.

Staining for NADPHd activity in area 17 of squirrel monkeys revealed an intense neuropil activity that was related to cortical layers, as also observed by cytochrome oxidase histochemistry (17). Sandell (15) reported similar results for Rhesus monkeys and demonstrated that primate visual cortex presents heterogeneous metabolic activity generating modular-like structures, such as blobs and stripes. These metabolic compartments have been described by means of other techniques such as cytochrome oxidase and cellular uptake of tritiated neurotransmitters $(17,24)$. Electrophysiological recordings suggest that units with different receptive field properties are selectively confined to zones of different metabolic activity (25). Nevertheless, the functional significance of this

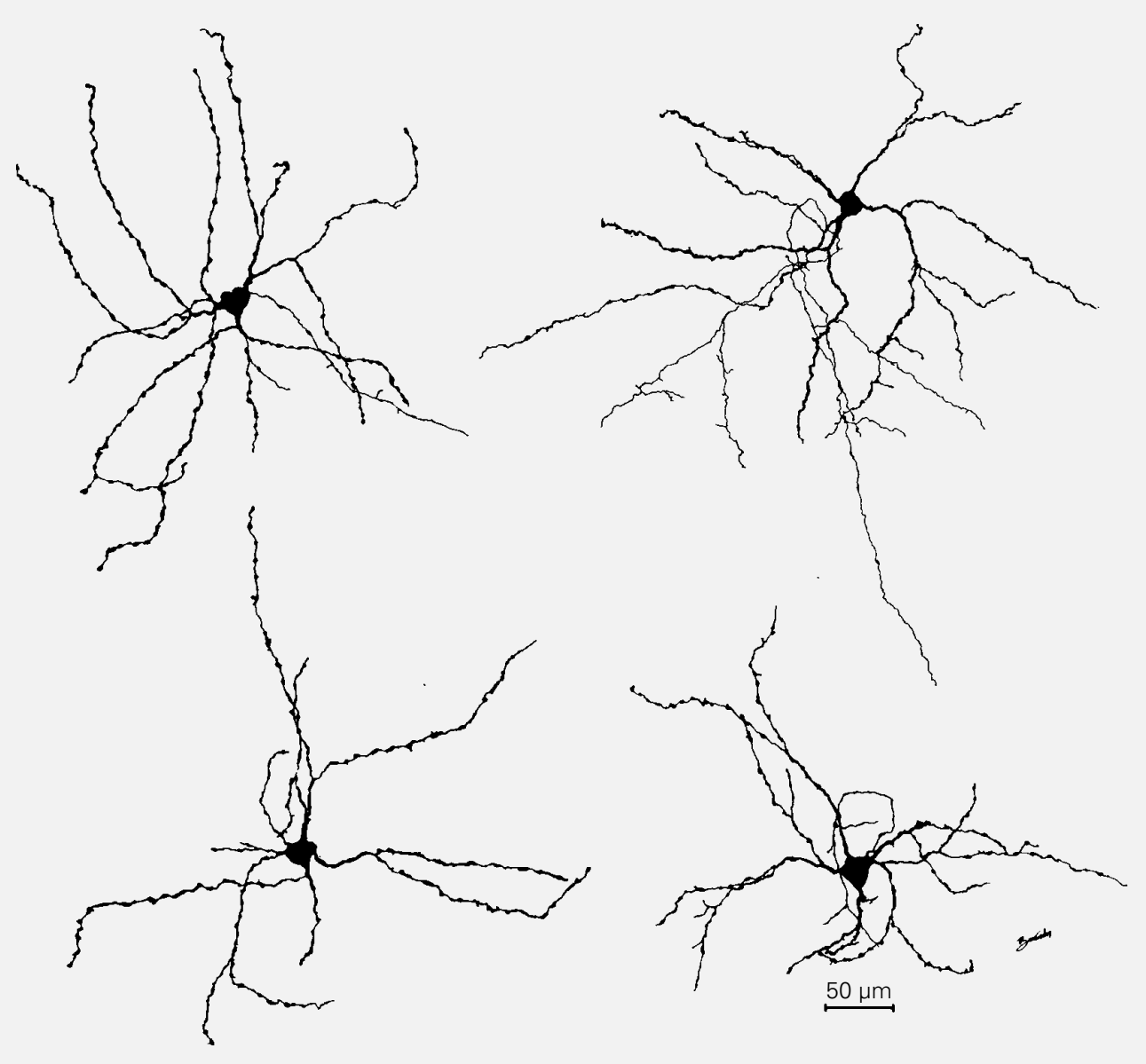

Figure 7 - Camera lucida drawings of four representative white matter neurons obtained in a tangential section. 
heterogeneity is still a subject of intense debate (26).

Sandell (15) demonstrated that cytochrome oxidase and NADPH-diaphorase blobs coincided using NADPHd and cytochrome oxidase histochemistry in alternate sections in Rhesus monkey visual cortex, and aligning them using blood vessels as landmarks. We used cytochrome oxidase and NADPHd histochemistry in both alternate and single sections (double labeling; data not shown) of area 17 of the squirrel monkey. Our results revealed that, at least in the operculum, NADPHd blobs do not always coincide perfectly with cytochrome oxidase blobs (Ref. 27 and the present paper). From a functional point of view, we do not know the significance of these results. It has been well established that NADPHd corresponds to bNOS in fixed brain tissue (4,7-10). NOS and cytochrome oxidase have markedly different functions in the central nervous system $(28,29)$ and their subcellular and cellular distributions are also rather different. Electron microscopy of NADPHd-positive cells demonstrated that formazan is dispersed along the neuron and cannot be associated with any specific cell organelle (30). On the other hand, electron microscopic analyses have revealed a completely different distribution for cytochrome oxidase which is a mitochondrial enzyme $(29,31,32)$. The morphological types of cytochrome oxidase-positive neurons in V1 (31) and V2 (32) are different from those revealed by NADPHd histochemistry. Cytochrome oxidase stains a good part of pyramidal cells that have not been labeled so far using NADPHd. In addition, most NADPHd-positive neurons were found in the white matter where cytochrome oxidase-positive neurons were not observed.

Since NOS and cytochrome oxidase have different molecular roles, we may assume that they should have different topographical distributions in the brain possibly determined by different factors. In that case, congruent zones of cytochrome oxidase and ni- tric oxide synthase blobs would be an epiphenomenon. On the other hand, NO has been suggested to be a retrograde messenger that stimulates glutamatergic presynaptic terminals creating a positive feedback loop (6). This would explain why the most metabolically active (cytochrome oxidase) regions are also rich in nitric oxide synthase. NO is also a potent cerebrovasodilator. Its release from nearby NOS-positive neurons can be elicited by increased neural activity (33). Thus, NO can be the link between enhancement of brain metabolism and the increase in cerebral blood supply (33). This hypothesis is coherent with co-localization of cytochrome oxidase (a metabolic enzyme) and NOS. It should be noted that in the present study we used the malic enzyme "indirect" method to label NADPHd activity. This technique requires intracellular metabolic enzymes to reduce NADP to NADPH which is used as a cofactor for bNOS (34). Thus, we could be labeling only a subpopulation of NOS-positive neurons that are more metabolically active. Nevertheless, Sandell (15) obtained the same results using both "direct" and "indirect" histochemical methods. Like Sandell, we chose the "indirect" method because it provides lower levels of nonspecific background activity.

NADPHd neuropil activity is very intense in monkey cortex and its origin is not well known. Aoki et al. (23), using polyclonal anti-NOS antibody in area V1 of monocular monkeys, described the subcellular distribution of this enzyme using electron microscopy. They observed that $80 \%$ of NOS immunoreactive profiles in lamina $4 \mathrm{C}$ are axon terminals. Reactive dendritic spines and shafts are also found in lamina $4 \mathrm{C}$ but they are more prevalent in the superficial laminae. This electron microscopy study did not reveal if these dendritic profiles are from the intensely NADPHd-labeled neurons or if other cell types, including pyramidal neurons, also present dispersed NOS immunoreactivity detected as diffuse neuropil staining 
by light microscopy. Subcellular distribution of cytochrome oxidase is heterogeneous in most neurons (29) and this can also be true for NOS. We also do not know if the neuropil pattern in monkey visual cortex originates from local, cortico-cortical, thalamocortical or different combinations of these projections. Our preliminary results with NADPHd histochemistry in the lateral geniculate nucleus (LGN) of squirrel and Cebus monkeys revealed a disappointingly small number of reactive neurons. This is also the case for Old World monkeys (23). No labeled neurons are found in the LGN when NOS immunohistochemistry is performed (23). However, enzymatic activity is strongly influenced by monocular deprivation both in New World (35) and Old World monkeys $(15,23)$. These studies demonstrated ocular dominance columns in monocular monkeys using NADPHd histochemistry $(15,35)$ or NOS immunohistochemistry (23).

It is also still unclear whether glial cells contribute to the neuropil pattern. Glial cells present both constitutive and inductive forms of NOS (36) and may correspond to the lightly stained cell bodies observed in our material. The small faintly labeled cells detected with NADPHd are by far much more numerous than the intensely labeled subpopulation. This is also the case for Old World monkeys $(15,23)$. In these cells NADPHd and NOS immunoreactivity are also co-localized (23). Since histochemical procedures do not reveal their morphology in detail we are not sure if they are neural cells. Aoki et al. (23) claimed that these cells are neurons. Nevertheless, their small somata suggest that they may be glial elements.
Further studies using specific neuronal and/ or glial markers are needed to clarify this issue.

Although the general pattern of NADPHd histochemistry is closely similar in Old World $(15,23)$ and New World monkeys (our results), some aspects of the distribution of heavily labeled neurons seem to be different. Sandell (15) demonstrated that most neurons in supragranular layers were inside enzyme-rich "patches" (blobs) (252 cells inside blobs vs 135 cells in interblob regions). This was not the case for squirrel monkeys in which the labeled neurons were evenly distributed. In this respect, our results are similar to those obtained by Aoki et al. (23). Another striking difference was the relative number of cells counted in layer $4 \mathrm{C}$. This layer is typically devoid of labeled cell somata both in New and Old World monkeys $(15,23)$, although it seemed to be more populated in squirrel monkeys. We found that $3.3 \%$ of neurons counted in $\mathrm{V} 1(\mathrm{~N}=2256$, including white matter cells) were in layer 4C. In all other layers the ratios were similar to those reported for Rhesus monkeys (15) but in layer $4 \mathrm{C}$ the percentage was more than ten times greater. This can be related to the absence of ocular dominance columns in squirrel monkeys (16). Nevertheless, the functional significance of such interspecific differences is not clear and demands further investigation.

\section{Acknowledgment}

We would like to acknowledge José Bertuedes Monteiro for the final art work on our camera lucida drawings. 


\section{References}

1. Thomas E \& Pearse AGE (1964). The solitary active cells. Histochemical demonstration of damage resistant nerve cells with a TPN-diaphorase reaction. Acta Neuropathologica, 3: 238-249.

2. Ferrante RJ, Kowall NW, Beal MF, Martin JB, Bird ED \& Richardson EP (1987). Morphologic and histochemical characteristics of a spared subset of striatal neurons in Huntington's disease. Journal of Neuropathology and Experimental Neurology, 46: 12-27.

3. Uemura Y, Kowall NW \& Beal MF (1990). Selective sparing of NADPH-diaphorasesomatostatin-neuropeptide $Y$ neurons in ischemic gerbil striatum. Annals of Neurology of the American Neurological Association, 27: 620-625.

4. Matsumoto T, Nakane M, Pollock JS, Kuk JE \& Förstermann U (1993). A correlation between soluble brain nitric oxide synthase and NADPH-diaphorase activity is only seen after exposure of the tissue to fixative. Neuroscience Letters, 155: 6164.

5. Bredt DS \& Snyder SH (1990). Isolation of nitric oxide synthase: a calmodulin requiring enzyme. Proceedings of the National Academy of Sciences, USA, 87: 682-685.

6. Garthwaite J (1991). Glutamate, nitric oxide and cell-cell signaling in the nervous system. Trends in Neurosciences, 14: 6067.

7. Bredt DS, Glatt CE, Hwang PM, Fotuhi M, Dawson TM \& Snyder SH (1991). Nitric oxide synthase protein and mRNA are discretely localized in neuronal populations of the mammalian CNS together with NADPH diaphorase. Neuron, 7: 615-624.

8. Dawson TM, Bredt DS, Fotuhi M, Hwang PM \& Snyder SH (1991). Nitric oxide synthase and neuronal NADPH diaphorase are identical in brain and peripheral tissues. Proceedings of the National Academy of Sciences, USA, 88: 7797-7801.

9. Hope BT, Michael GJ, Knigge KM \& Vincent SR (1991). Neuronal NADPH-diaphorase is a nitric oxide synthase. Proceedings of the National Academy of Sciences, USA, 88: 2811-2814.

10. Vincent SR \& Kimura H (1992). Histochemical mapping of nitric oxide synthase in the rat brain. Neuroscience, 46: 755-784

11. Franca JG \& Volchan E (1995). NADPH diaphorase histochemistry as a marker for barrels in rat somatosensory cortex. Brazilian Journal of Medical and Biological Research, 28: 787-790.
12. Picanço-Diniz CW, do Nascimento JLM \& Friedlander MJ (1993). Histochemical evaluation of nitric oxide synthase levels in guinea pig visual cortex after Lnitroarginine administration in vivo and in vitro. The Association for Research in Vision and Ophthalmology (ARVO) Annual Meeting, Sarasota, Florida. Investigative Ophthalmology and Visual Science, 34: 1175 (Abstract).

13. Volchan E \& Franca JG (1994). Distribution of NADPH-diaphorase-positive neurons in the opossum neocortex. Brazilian Journal of Medical and Biological Research, 27: 2431-2435.

14. Mizukawa K, Vincent SR, McGeer PL \& McGeer EG (1988). Reduced nicotinamide adenine dinucleotide phosphate (NADPH)diaphorase-positive neurons in cat cerebral white matter. Brain Research, 461: 274-281.

15. Sandell JH (1986). NADPH-diaphorase histochemistry in the macaque striate cortex. Journal of Comparative Neurology, 251: 388-397.

16. Hendrickson AE, Wilson JR \& Ogren MP (1978). The neuroanatomical organization of pathways between the dorsal lateral geniculate nucleus and the visual cortex in old world and new world primates. Journal of Comparative Neurology, 182: 123-136.

17. Horton JC (1984). Cytochrome oxidase patches: a new cytoarchitectonic feature of monkey visual cortex. Philosophical Transactions of the Royal Society of London, Series B, 304: 199-253.

18. Martin KAC \& Whitteridge D (1984). Form, function and intracortical projections of spiny neurones in the striate visual cortex of the cat. Journal of Physiology, 353: 463-504.

19. Peters A \& Regidor J (1981). A reassessment of the forms of non-pyramidal neurons in area 17 of cat visual cortex. Journal of Comparative Neurology, 203: 685716.

20. Fairén A, De Felipe J \& Regidor J (1984). Non-pyramidal neurons - general account. In: Peters A \& Jones EG (Editors), Cerebral Cortex: Cellular Components of the Cerebral Cortex. Vol. 1. Plenum Press, New York, London, 201-253.

21. Tömböl T (1984). Layer VI cells. In: Peters A \& Jones EG (Editors), Cerebral Cortex: Cellular Components of the Cerebral Cortex. Vol. 1. Plenum Press, New York, London, 479-519.
22. Dinerman JL, Dawson TM, Schell MJ, Snowman A \& Snyder SH (1994). Endothelial nitric oxide synthase localized to hippocampal pyramidal cells: Implications for synaptic plasticity. Proceedings of the National Academy of Sciences, USA, 91: 4214-4218.

23. Aoki C, Fenstemaker S, Lubin M \& Go C$G$ (1993). Nitric oxide synthase in the visual cortex of monocular monkeys as revealed by light and electron microscopic immunocytochemistry. Brain Research, 620: 97-113.

24. Carroll EW \& Wong-Riley MTT (1985). Correlation between cytochrome oxidase staining and the uptake and laminar distribution of tritiated aspartate, glutamate, $\gamma$ aminobutyrate and glycine in the striate cortex of the squirrel monkey. Neuroscience, 15: 959-976.

25. Livingstone MS \& Hubel DH (1984). Anatomy and physiology of a color system in the primate visual cortex. Journal of Neuroscience, 4: 309-356.

26. Allman J \& Zucker S (1990). Cytochrome oxidase and functional coding in primate striate cortex: a hypothesis. Cold Spring Harbor Symposium on Quantitative Biology, 55: 979-982.

27. Picanço-Diniz CW, Martin KAC, Franca JG, Quaresma JAS, do Nascimento JLM \& Friedlander MJ (1992). A new "blob" system in the visual cortex of the squirrel monkey revealed by nitric oxide synthase. Society for Neuroscience Abstracts, 18 (Part 1): 210.

28. Bredt DS \& Snyder SH (1992). Nitric oxide: a novel neuronal messenger. Neuron, 8: 3-11.

29. Wong-Riley MTT (1989). Cytochrome oxidase: an endogenous metabolic marker for neuronal activity. Trends in Neurosciences, 12: 94-101.

30. Vincent SR \& Johansson O (1983). Striatal neurons containing both somatostatin and avian pancreatic polypeptide (APP)-like immunoreactives and NADPH-diaphorase activity: a light and electron microscopic study. Journal of Comparative Neurology, 217: 264-270.

31. Carroll EW \& Wong-Riley MTT (1984). Quantitative light and electron microscopic analysis of cytochrome oxidase-rich zones in the striate cortex of squirrel monkeys. Journal of Comparative Neurology, 222: 1-17. 
32. Wong-Riley MTT \& Carroll EW (1984). Quantitative light and electron microscopic analysis of cytochrome oxidase-rich zones in VII prestriate cortex of squirrel monkeys. Journal of Comparative Neurology, 222: 18-37.

33. Iadecola C (1993). Regulation of the cerebral microcirculation during neural activity: is nitric oxide the missing link? Trends in Neurosciences, 16: 206-214.
34. Sandell JH (1985). NADPH diaphorase cells in the mammalian inner retina. Journal of Comparative Neurology, 238: 466472.

35. Do Nascimento RSV (1995). Estudo das colunas de dominância ocular do Cebus apella pela histoquímica de NADPHdiaforase. Master's thesis, Universidade Federal do Pará/Museu Paraense Emílio Goeldi.
36. Murphy S, Simmons ML, Agullo L, Garcia A, Feinstein DL, Galea E, Reis DJ, MincGolomb D \& Schwartz JP (1993). Synthesis of nitric oxide in CNS glial cells. Trends in Neurosciences, 16: 323-328. 